\title{
Electroporation and morphogenic potential of Gentiana kurroo (Royle) embryogenic cell suspension protoplasts
}

\author{
ANNA WóJCIK, JAN J. RYBCZYŃSKI * \\ Department of Experimental Plant Biology, Botanical Garden - Center for Biological Diversity Conservation, \\ Polish Academy of Sciences, Warszawa, Poland \\ *Corresponding author: jjryb@obpan.pl
}

\begin{abstract}
This article presents our further in vitro studies into the morphogenic potential of gentian cells, organs, and tissues after modification of their genome. The objective was to study the effect of electroporation and the introduction of foreign genes on the morphogenic potential of Gentiana kurroo embryogenic cell suspension protoplasts. Protoplasts were electroporated with DNA plasmids carrying nptII and bargenes. The stability of cell membranes, the contents of electroporation buffer, the length of electric pulse, the number of pulses and the strength of the electric field were studied. We determined the highest electroporation efficiency by evaluating the highest protoplast survival rate under specific physical conditions. The best results were achieved in the presence of EB1 electroporation buffer where the viability of protoplasts was $70.1 \%$. Protoplast survival at this higher level required culture temperatures near $0^{\circ} \mathrm{C}$, and a $20 \mu$ s electric pulse with an electric field of $1.0 \mathrm{kV} / \mathrm{cm}$. After seven days of agarose embedded protoplast culture, a selective agent - kanamycin - was introduced to the medium. The cell transformation effect was improved by a long term culture of callus, regenerated somatic embryos and transformants in the presence of $50 \mathrm{mg} / 1$ kanamycin.
\end{abstract}

Key words: electroporation buffer, electric field, electric pulse, kanamycin resistance protoplast viability, plating efficiency, transformant regeneration

$\begin{array}{ll}\text { Abbreviations } \\ \text { AS } & \text { - adenine sulfate } \\ \text { BAP } & \text { - benzylaminopurine } \\ \text { Dicamba } & \text { - 3,6-dichloro-2-methoxybenzoic acid } \\ \text { DNA } & \text { - desoxyribonucleic acid } \\ \text { EB1 } & \text { - electroporation buffer no. } 1 \\ \text { EB2 } & \text { - electroporation buffer no. } 2 \\ \text { GA } & \text { - gibberelic acid } \\ \text { kan } & \text { - kanamycin }\end{array}$

\section{Introduction}

The alternatives to Agrobacterium mediated plant cell transformation are biolistic particle bombardment or protoplast chemical and physical treatments. Electroporation consists of the treatment of plant cells with short high voltage electric pulses. The electric pulse shock causes brief permeability of the plasmalemma for high molecular particles, such as DNA (Bates, 1989). The DNA movement is via pores formed after electric pulses in the cytoplasmic membrane (Sowers, 1992). The pores are of temporal character and they are related to the increased dipole moment of hydrophilic heads building cell membrane lipids. The dipole heads of phos-

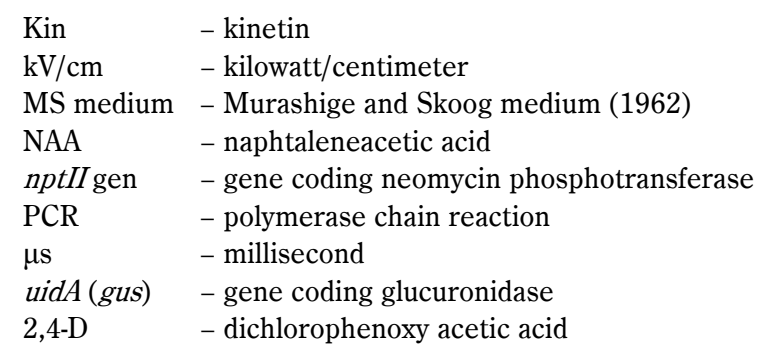

pholipids dislocate in the direction of the electric field, which causes breaks in the continuity of the cell membrane (Kinosita and Tsong, 1977; Neuman et al., 1982, 1996). In addition to various biological parameters connected with the selection of the proper source of protoplasts and their culture conditions, the pivotal requirement for successful cell transformation are the physical conditions of electroporation, specifically the voltage of the electric field, the number of pulses and length of pulse duration (Sauders et al., 1995).

The specific effect of the electric field on tissues cultured in vitro was determined by analyzing the growth of isolated protoplasts as well as with protoplast-derived 
calli of Colt cherry (Prunus avium $\times$ pseudocerasu). The plant regeneration capacity of electroporated tissues was also investigated. The callus obtained from the protoplasts and subjected to three successive exponential pulses at $250 \mathrm{~V}$ or $500 \mathrm{~V}$ showed the largest fresh weight increases between subcultures. It also exhibited the highest morphogenic potential, as manifested by increased frequency of plant regeneration calculated based on the number of shoots per callus. These shoots, in turn, expressed (once more) a higher potential for producing a more prolific root system when compared to those derived from non-electropulsed protoplasts of Colt cherry (Ochatt et al., 1988).

There are numerous examples of the use of electroporation in transformation experiments with organized plant structures such as immature embryo or somatic embryos. Embryo and somatic embryos at the torpedo stage of coffee have been electroporated with DNA containing gus and bar genes, and plant regeneration through secondary somatic embryogenesis has been obtained (Barton et al., 1991). The presence of gus and bar genes has been confirmed by PCR reaction performed on DNA isolated from regenerated plants (Fernandez-Da Silva and Menendez-Yuffa, 2003). Similar experiments are needed concerning representative species of the Gentianaceae family.

The Gentianaceae family consists of about 1700 species but only 28 are used for plant tissue culture and biotechnology. Among these, Gentiana kurroo $(2 \mathrm{n}=26)$ (Behera, 2011) is a critically endangered species endemic to the northwestern Himalayas (Khuroo, 2005). This is a small perennial herb with a stout rhizome bearing a decumbent flowering stem. Due to its multiple uses (Behera, 2011), it is a species that is being over exploited in its natural habitat. Hence, it qualifies as an important endangered medicinal plant and is protected by Indian Law (Khuroo, 2005). Its secondary metabolite spectrum is the richest of all gentian species, even comparable to $G$. lutea. These secondary compounds - gentiopicrine, gentiamarin and the alkaloid gentianinare are used for the treatment of inflammation, pain, fever, and hepatitis (Latif, 2006).

G. kurroo's reproductive biology is connected with its flowers being dichogamous due to protardy. Stigmatic lobes remain adpressed until almost complete anther dehiscence. The stigma becomes receptive to pollen germination about one week after initiation of anther dehi- scence. The flowers are cross-pollinated (Raina et al., 2003). The plant is characterized by being mostly wild and not domesticated due to its poor seedling establishment in nature. However, these plants produce abundant seeds. Seed germination under laboratory conditions commenced from six to twenty eight days with a total record of about 70\% (Raina et al., 2011, 2003; Tomar et al., 2012). Macroproliferation by rhizomes appears to be an alternative, easy and effective technique for the multiplication and conservation of this herb (Tomar, 2011).

The first papers summarizing the achievements of gentian plant tissue cultures were published in 1988 and in 1991 (Barešová, 1988; Miura, 1991). Since then, considerable progress in the biochemistry and biotechnology of gentians has been achieved. The establishment of a green leaf mesophyll cell cultures and cell suspension protoplast culture procedures have provided a significant basis for progress in gentian somatic cell genetic manipulation (Jomori et al., 1995; Meng et al., 1996; Fiuk and Rybczyński, 2007; Tomiczak and Rybczyński, 2015). Initially, possibilities were presented for establishing plant multiplication of $G$. kurroo by culturing the shoot tips and nodal segments on MS medium (Murashige and Skoog, 1962) supplemented with BAP (benzylaminopurine) and NAA (naphthaleneacetic acid). For the most effective rooting, individual shoots with 3-4 nodes were implanted on semisolid hormone-free MS medium supplemented with $6 \%$ sucrose (Sharma, 1993). The MS medium supplemented with $0.5 \mathrm{mg} / \mathrm{l} \mathrm{IAA}$ and $0.8 \mathrm{mg} / \mathrm{l}$ BAP stimulated more than $80 \%$ of apical meristems for rich proliferation (Kaushal et al., 2014). Randomly amplified polymorphic DNA (RAPD) and karyotypic analysis showed the lack of variation, and hence the genetic stability of regenerants, and confirmed the efficacy of the protocol for micropropagating plants of $G$. kurroo over a ten year time period (Kaur et al., 2009). Significant progress in vegetative plant cell manipulation occurred when the somatic embryogenesis of primary explants was described for a few gentian species (Mikuła, 1996a, 1996b). Among the studied gentians, G. kurroo appeared to be a highly embryogenic species with tremendous morphogenic potential. Both seedling and leaf explants have been used for culture initiation and the establishment of cell suspensions (Fiuk and Rybczyński, 2008). The derived calli appear to be an excellent source of embryogenic cells and their protoplasts. A very high yield of regenerants via somatic embryogenesis from proto- 



Fig. 1. Diagram of procedures involved in electroporation experiments of G. kurroo (Royle) embryogenic cell suspension protoplasts

plast bead culture has confirmed the usefulness of this type of protoplast culture for gentian cell manipulation (Fiuk and Rybczyński, 2007). The cell suspension cultures also produce embryogenic aggregates and somatic embryos which could be used for proteomic studies (Fiuk and Rybczyński, 2007; Niedziela and Rybczyński, 2014). Somatic embryogenesis is a complex process that allows the performance of multidisciplinary studies into the mechanism of embryo induction and its development. There are a huge number of indications that this phenomenon also has great potential for plant propagation (Rybczyński et al., 2007).

This research describes the effect of electroporation and the introduction of foreign genes ( $g u s$ and $n t p \mathrm{II}$ ) on the morphogenic potential of $G$. kurroo embryogenic cell suspension protoplasts (Fig. 1).

\section{Methods}

\section{Cell suspension initiation and culture}

Seedling explants of G. kurroo (cotyledons, hypocotyles and roots) were implanted on an MS medium supplemented with $1.0 \mathrm{mg} / \mathrm{l} \mathrm{Kin} \mathrm{(kinetin)} \mathrm{and} 0.5 \mathrm{mg} / 1$ 2,4-D (2,4-dichlorophenoxy acid) to induce an embryogenic callus culture. A hypocotyl-derived embryogenic callus was used for cell suspension culture establishment on an MS medium supplemented with BAP (benzylaminopurine), NAA (naphthaleneacetic acid), Dicamba (3,6-dichloro-2-methoxybenzoic acid) and AS (adenine sulfate) (Fiuk and Rybczyński, 2007). Cell suspensions were initiated by transferring $1.0 \mathrm{~g}$ of embryogenic tissue to $20 \mathrm{ml}$ of liquid medium in $100 \mathrm{ml}$ conical flasks. Once established, the cell suspension cultures were maintained as $80 \mathrm{ml}$ aliquots in large $200 \mathrm{ml}$ conical flasks, with agitation on a rotary shaker at $120 \mathrm{rpm}$, under diffused light $20 \mu \mathrm{M} \mathrm{m}^{-2} \mathrm{~s}^{-1}$ at $22^{\circ} \mathrm{C}$. Subcultures of the cell suspension were made every seven days.

For the evaluation of the embryogenic suspension, the production of embryoids was measured by implanting cell suspension fractions (500, 500-300, 300-150 and $150 \mu \mathrm{m}$ ) on MS medium supplemented with $0.5 \mathrm{mg} / \mathrm{l}$ $\mathrm{GA}_{3}$ (gibberellic acid), $1.0 \mathrm{mg} / 1 \mathrm{Kin}+80 \mathrm{mg} / 1 \mathrm{AS}$.

\section{Protoplast isolation and culture}

Protoplasts were isolated from embryogenic cell suspensions which were subcultured every 7 days. One gram of cell suspension was transferred to deep Petri plates and immersed in $20 \mathrm{ml}$ of enzyme mixture. Powdered enzymes - Cellulase RS (YakultHonsha Co., LTD) - 1.5\%; Driselase (Fluka AG) - 0.5\%; Hemicellulase (Sig- 
ma) - 0.25\%; Macerozyme R10 (YakultHonsha Co., LTD) - 1.5\%; Pectolyase (Seishin Pharmaceutical Co., LTD) - $0.04 \%$ - were dissolved in a protoplast washing solution (Frearson et al., 1973). Non-soluble debris were removed by centrifugation. The supernatant was supplemented with $9 \%$ of mannitol and 5.0 mM MES (2-[N-Morpholino] ethanesulfonic acid). pH was adjusted to $5.8(\mathrm{NaOH})$. The mixture was filter-sterilized using a $0.2 \mu \mathrm{m}$ membrane filter of Sartorius sterilization system in the cold.

The plant material was incubated in the enzyme mixture for $12 \mathrm{hrs}$ at $28^{\circ} \mathrm{C}$ in the dark with $30 \mathrm{rpm}$ agitation. The released protoplasts were filtered through a plastic sieve $(45 \mu \mathrm{m})$ and centrifuged for $10 \mathrm{~min}$ at $180 \mathrm{rpm}$ on an MPW-360 centrifuge (MPW Med. Instruments, Warsaw, Poland). The protoplast pellet was resuspended and washed three times with a protoplast washing solution supplemented with $90.0 \mathrm{~g} / 1$ mannitol. The protoplast yield and densities were determined with a Fuchs-Rosenthal hermocytometer. Protoplasts were embedded in Sea Plaque agarose-gelled PCM medium (MS without $\mathrm{NH}_{4} \mathrm{NO}_{3}+30.0 \mathrm{~g} / 1$ glucose $+3.0 \mathrm{~g} / 1$ Glutamine $+0.5 \mathrm{mg} / 1$ 2,4-D + $1.0 \mathrm{mg} / 1 \mathrm{Kin}+9.0 \%$ mannitol, $\mathrm{pH}=5.8)$ and cultured in droplets of $100 \mu \mathrm{l} .10$ droplets per $5.0 \mathrm{~cm}$ Petri plate were covered by $2.0 \mathrm{ml}$ of a liquid PCM medium.

\section{The effect of kanamycin concentration on protoplast survival}

Freshly isolated protoplasts were embedded in agarose PCM and, in the form of $100 \mu \mathrm{l}$ drops of medium containing protoplasts, these were dropped into a $\varnothing 5.0 \mathrm{~cm}$ plastic Petri plate. Later, once the droplets (10 per plate) had jellified, Petri plates were filled with $2.0 \mathrm{ml}$ of PCM. After seven days of culture, the medium was exchanged for the PCM supplemented with 25.0, 50.0, 75.0 or $100.0 \mathrm{mg} / 1 \mathrm{kanamycin}$ for transformant selection. The experiment was repeated five times for each antibiotic concentration. The culture period lasted four weeks. The effect of kanamycin concentration on the growth and development of cultured protoplasts was evaluated using a Vanox Olympus light microscope, and this served as the basis for the choice of the antibiotic concentration for further experiments.

\section{Esherichia coli culture and plasmid DNA isolation}

Escherihia coli strain HB 101 with plasmid pBI (Jefferson et al., 1987) carrying an npt II gene encoding neomycin phosphotransferase under a nos promoter and a gus gene encoding $\beta$-glucuronidase under a CaMV35S promoter was the source of DNA used for electroporation experiments.

$E$. coli HB 101 cells were maintained on LB medium (Schaad, 1988) containing $5.0 \mathrm{~g} / 1$ yeast extract, $10.0 \mathrm{~g} / 1$ tryptophan, and $10.0 \mathrm{~g} / \mathrm{l} \mathrm{NaCl}, \mathrm{pH} 7.2$. Plasmids were isolated by alkaline lysis with some modifications (Sambrook and Russell, 2001). The bacteria cells were treated with $15 \mu \mathrm{l}$ Rase $(10 \mathrm{mg} / \mathrm{ml})$ in solution I (50 mM glucose, $25 \mathrm{mM}$ Tris-HCL, $\mathrm{pH}=8.0,10 \mathrm{mM}$ EDTA $\mathrm{pH}=8.0$ ). Later, the sample was supplemented with $200 \mu$ solution II (0.2 MNaOH, $1 \%$ SDS), shaken gently and incubated in ice for $5 \mathrm{~min}$, and then $150 \mu$ of frozen $7.5 \mathrm{M}$ ammonium acetate was added. The sample was left for $10 \mathrm{~min}$ on ice, followed by centrifugation at $14,000 \mathrm{rpm}$. The DNA was precipitated with $900 \mu \mathrm{l}$ of $96 \% \mathrm{EtOH}$ for $2 \mathrm{~min}$. at room temperature and centrifuged at $13,000 \mathrm{rpm}$ for $5 \mathrm{~min}$. The next step of preparation consisted of the washing of the DNA sample with 70\% EtOH and centrifugation at $13 \mathrm{~K}$ rpm for $5 \mathrm{~min}$. Finally, the sample was dried at room temperature and diluted in $30 \mu \mathrm{H}_{2} 0$. All centrifugations in this procedure were performed in $1.5 \mathrm{ml} \mathrm{Ep}$ pendorf tubes and on a SIGMA 2-16PK centrifuge (Sigma Laborzentrifugen GmbH, Osterode am Harz, Germany).

Protoplasts were electroporated using the Generator of Electric Pulses BTX ECM 2001 Electro Cell Manipulator together with Cuvette Safety Stand 630B in BTX Electroporation Cuvettes Plus with $2.0 \mathrm{~mm}$ Gap Cuvettes. Protoplasts freshly isolated from the embryogenic cell suspension were suspended in an electroporation buffer at a density of $4 \times 10^{5}$ per $\mathrm{ml}$ in the presence of $50 \mu \mathrm{g} / \mathrm{ml}$ plasmid DNA. Two electroporation buffers were tested: EB1 (70 mM KCl, 5 mM MgCl${ }_{2}, 0.1 \%$ MES, 9\% mannitol, $\mathrm{pH}=5.8)$ and $\mathrm{EB} 2\left(4 \mathrm{mM} \mathrm{MgCl}_{2}, 0.5 \% \mathrm{MES}, 9 \%\right.$ mannitol, $\mathrm{pH}=5.6$ ). Before electric current treatment, the cuvettes with protoplasts and plasmids in the electroporation buffer were placed in ice for $10 \mathrm{~min}$.

The electroporation parameters tested were: the length of the electric pulse $(20,30,40 \mu$ s and $1.0,2.0$, and $5 \mathrm{~ms}$ ), the number of pulses (1 or 2), the electric field strength $(0.0-1.75 \mathrm{kv} / \mathrm{cm})$, and the temperature (on ice; about $0^{\circ} \mathrm{C}$ and room temperature; about $20^{\circ} \mathrm{C}$ ) treatment after electroporation. The experiments were repeated five times for each of the above experimental conditions.

After the electric current treatment, protoplasts were incubated at room temperature or on ice for $10 \mathrm{~min}$, followed by protoplasts being washed with liquid 


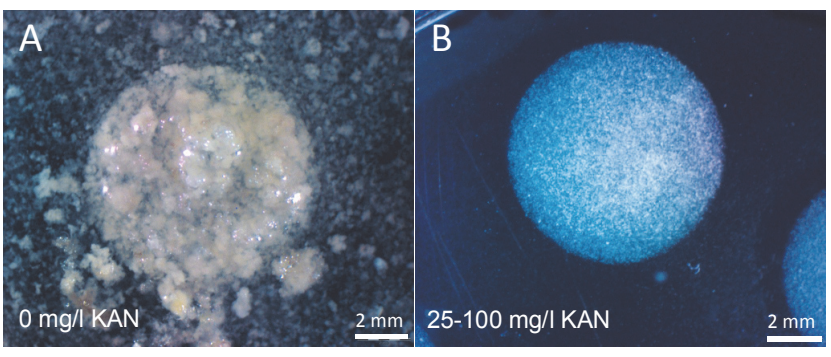

Fig. 2. Sea Plague Agarose embedded control protoplast and kanamycin treated protoplasts of $G$. kurroo after four weeks of the experiment. A) The overgrowth of callus formed by control protoplast culture. Notice spontaneous cell aggregates - shedding from agarose bead into liquid medium. B) Protoplast-derived cell division suppressed culture exposed to $25-100 \mathrm{mg} / 1$ kanamycin applied after 7 days of culture

PCM medium and left at room temperature for $24 \mathrm{hrs}$. Then, the liquid medium was substituted by a PCM agarose gelling medium, and cultures were maintained as droplets with a protoplast density of $1 \times 10^{5} / \mathrm{ml}$. A total of $2.0 \mathrm{ml}$ of liquid PCM medium was then added to each Petri plate. After one week, the PCM medium was substituted with the same medium supplemented with $50 \mathrm{mg} / \mathrm{l} \mathrm{kanamycin}$. Complete osmotic pressure reduction was achieved as follows: mannitol was reduced from $9 \%$ to $6 \%$ after 3 weeks and then to $3 \%$ two weeks later with final reduction of osmotic pressure by week 8 .

Agarose droplets with protoplasts already developed into multicellular aggregates were transferred to CSIM medium (MS + $0.5 \mathrm{mg} / 1$ 2,4-D + $1.0 \mathrm{mg} / 1$ Kinetin) supplemented with the same kanamycin concentration. Mock electroporation was performed as above, except that the electric current was not used. The protoplast morphogenic potential evaluation required a control culture which was carried out as described elsewhere (Fiuk and Rybczyński, 2007).

\section{Protoplast viability and transient gene expression evaluation in the presence of kanamycin}

Protoplast viability evaluation was performed twice using $0.01 \%$ FDA (Fluorescein diacetate) and UV light $\lambda=485$ on a Vanox (Olympus) microscope: after $24 \mathrm{hrs}$ and after 7 days of culture. After 7 days, the frequency of cell divisions was also scored. The transient gene expression was evaluated by the $\beta$-glucuronidase test. The histochemical activity of $\beta$-glucuronidase was evaluated again when the calli reached a prominent size and dissection of small pieces from the tissue did not harm subsequent proliferation.

\section{Transformant regeneration from protoplast culture exposed to electroporation}

After seven weeks of culture, agarose droplets with prominent calli were transferred to CSIM + Kan medium. The regenerated structures were transferred to a TPM medium (MS + $30.0 \mathrm{~g} / 1$ sucrose $+8.0 \mathrm{~g} / 1$ agar, $\mathrm{pH}=5.8$ ) supplemented with $50 \mathrm{mg} / \mathrm{l}$ kanamycin.

\section{Evaluation of GUS activity}

The expression of gus in cells, calli and leaf fragments of transformants was assayed using 5-bromo-4chloro-3-indolylglucuronide (X-Gluc) as a substrate. The tissues were incubated in the reaction mixture including 1.0 mM X-Gluc in DMSO, 20.0 mM phosphate buffer $\mathrm{pH}=7.0,0.25 \mathrm{mM}$ Triton X-100, $3.12 \mathrm{mM}$ methanol. The plant material was covered with a reaction mixture and maintained at $37^{\circ} \mathrm{C}$ for $24 \mathrm{hrs}$ in the dark. After that, the tissues were treated with $70 \%$ ethanol (three times) to extract chlorophyll from them in order to visualize a blue pigment (dichloro-dibromoindigo). The blue stain is the effect of GUS activity. Finally, the tissues were fixed with Carnoy's fixative (acetic acid/ethanol: v/v 1:3).

\section{PCR analysis of regenerated plants}

In order to confirm the transgenesis, primers for the marker nptIIgene (selection gene) and for the gene uidA (gus reporter gene) were used for testing. For the PCR amplification of a $700 \mathrm{bp}$ fragment of the nptII gene, the following starters have been used: (5'-GAGGCTATTCGG CTATGACTG-3') and (5'-ATCGGGAGCGGCGATACCG TA-3') (Dong and McHughen, 1993). Next, the following thermal profile was adopted: $95^{\circ} \mathrm{C} 15 \mathrm{~min} ., 30 \times\left(94^{\circ} \mathrm{C}\right.$ 30 sec., $56^{\circ} \mathrm{C} 30$ sec., $72^{\circ} \mathrm{C} 60$ sec.), $72^{\circ} \mathrm{C} 5$ min and $4{ }^{\circ} \mathrm{C}$. For the uidA gene, the following starters were tested: 1 - (5'-TTATCTCTATGAACTGTGCGTCA-3 $\left.{ }^{\prime}\right)$ and 2 (5'- TTGGACATACCATCCGTAATAA-3') with amplification of $679 \mathrm{bp}$. Primers were designed according to the Primer3 program on the basis of uidA gene sequences found in the NCBI database (National Center for Biotechnology Information 2008). After that, the following thermal profile was adopted: $95^{\circ} \mathrm{C} 15 \mathrm{~min} ., 30 \times\left(94^{\circ} \mathrm{C} 30\right.$ sec., $\left.51^{\circ} \mathrm{C} 1 \mathrm{~min} ., 72^{\circ} \mathrm{C} 2 \mathrm{~min}\right), 72^{\circ} \mathrm{C} 10 \mathrm{~min}$ and $4^{\circ} \mathrm{C}$.

\section{Statistical analysis}

A statistical analysis was performed with the application of the Statgraphics Plus4.1 program. The number of samples and their size, and the number of repetitions of experiments are presented. 


\section{Results}

Electroporation experiments were carried out on freshly isolated protoplasts of Gentiana kurroo embryogenic cell suspensions. Electroporated DNA plasmid derived from the HB101 E. coli strain carried two gene markers: $n p t I I$ (selection) and gus (reporter). Successful electroporation experiments required the determination of the protoplast viability, the content of the electroporation buffer, the length of the electric pulse, the number of pulses and the strength of the electric fields applied. Long-term kanamycin treatment of calli resulted in a selection of regenerants.

\section{The effect of kanamycin on the growth and development of protoplasts in control cultures}

To assess the effect of kanamycin on the cell division and growth of protoplast cultures, kanamycin was used at $0.0,25.0,50.0,75.0$, and $100.0 \mathrm{mg} / \mathrm{l}$. The use of kanamycin significantly blocked cell divisions of protoplasts and, at $25-75 \mathrm{mg} / 1$, it decreased cell division in protoplastderived cultures four-fold. The highest level of kanamycin $(100.0 \mathrm{mg} / \mathrm{l})$ completely blocked cell division and no further development of the culture was observed. In contrast, those control cultures which expressed a morphogenic potential by forming a callus and regenerating plants when treated with kanamycin did not form a callus and were not able to regenerate plants (Fig. 2).

\section{The effect of the electroporation buffer on protoplast survival}

The effect of the buffer composition on protoplast survival was studied after $24 \mathrm{hrs}$ and at 7 days of culture of freshly isolated protoplasts. After one week of culture, protoplast electroporation in the richer EB1 medium resulted in a protoplast viability of $70.1 \%$, while EB2 buffer supported a significantly lower level of survival (55.8\%). Protoplast viability was higher at room temperature than on ice, where it dropped to as low as $60 \%$. Conversely, when assessed after 7 days, which led to nutrient protoplast starvation, protoplast survival was higher on ice than at room temperature (Fig. 3).

\section{Effect of electric field on protoplast survival and plating efficiency}

The effect of the electric field voltage on protoplast survival was evaluated twice: at $24 \mathrm{hrs}$ and 7 days. A high electric field voltage significantly decreased the protoplast survival, irrespective of the temperature at
A

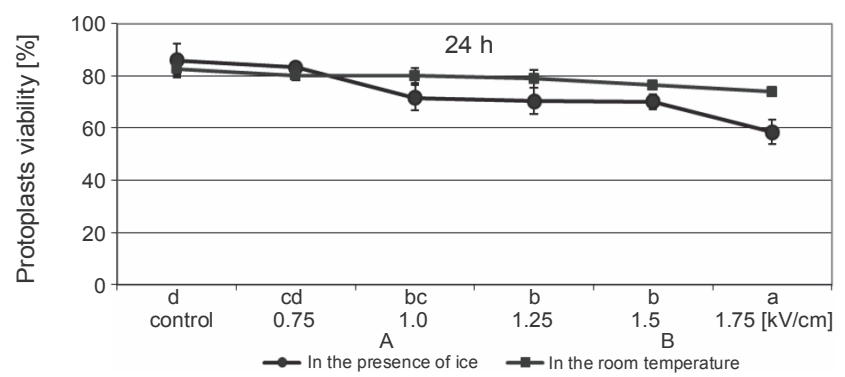

B

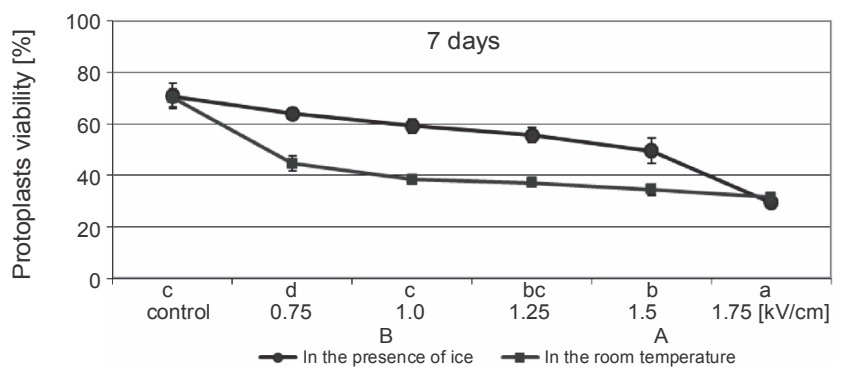

Fig. 3. The effect of temperature (at $0^{\circ} \mathrm{C}$ and $20^{\circ} \mathrm{C}$ ) and electric field current ( 1 puls, $20 \mu$ s long) on viability of $G$. kurroo protoplasts evaluated A) $24 \mathrm{hrs}$ and B) 7 days after electroporation (values described by the same letters and the size of characters are not significantly different, $p>0.05$ )

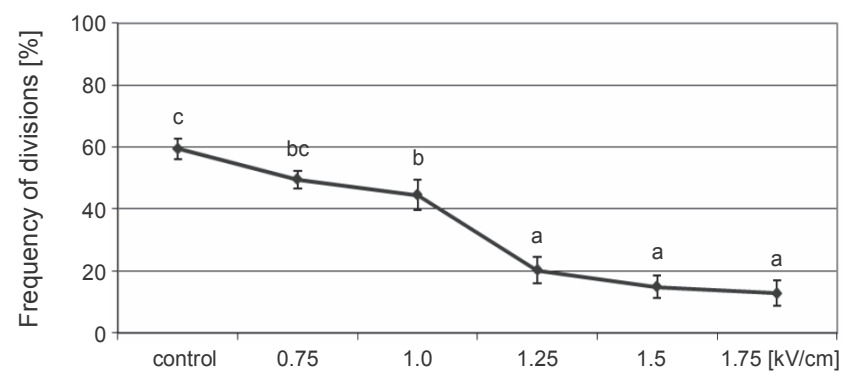

Fig. 4. The effect of electric field on frequency of G. kurroo protoplast cell division after one pulse of $20 \mu$ s duration. Protoplasts were incubated on ice (data marked by the same letters are not statistically different, $p>0.05$ )

which protoplasts were maintained following electroporation. At the lowest voltage $-0.75 \mathrm{kV} / \mathrm{cm}-44.6 \%$ of protoplasts survived, while at the highest voltage $(1.75 \mathrm{kV} / \mathrm{cm})$ only $31.4 \%$ survived. Protoplast incubation on ice produced similar results, with a protoplast survival of $63.8 \%$ at $0.75 \mathrm{kV} / \mathrm{cm}$ and $29.3 \%$ at $1.75 \mathrm{kV} / \mathrm{cm}$ after one week of culture (Fig. 4).

Non-electroporated protoplasts showed a plating efficiency of $59.4 \%$. The lowest electric pulse voltage $(0.75 \mathrm{kV} / \mathrm{cm})$ reduced the protoplast plating efficiency to 
$49.5 \%$, while further increases in the electric field strength up to $1 \mathrm{kV} / \mathrm{cm}$ resulted in a protoplast division reduction to $44.53 \%$. These data, however, were not significantly different. The elevation of electric field voltage above $1 \mathrm{kV} / \mathrm{cm}$ dramatically decreased protoplast division, but results were not significantly different from those for 1.25 or $1.75 \mathrm{kV} / \mathrm{cm}$.

\section{Number of pulses}

The number of pulses had a significant effect on the viability and frequency of the cell division of protoplasts. Thus, the percentage of viable protoplasts was nine-fold lower with two successive electric pulses as compared to a single one. With one pulse, the frequency of protoplast division was $44.53 \%$, and this dropped to $6.8 \%$ with two pulses.

\section{The effect of short and long time electric pulse treatment on protoplast viability and division}

To study the effect of the length of an electric pulse on protoplast viability, five durations of pulses were selected: from 20, 30, $40 \mu \mathrm{s}$; and 1.0, 2.0 and $5 \mathrm{~ms}$. The two longest pulses significantly reduced protoplast viability counted after $24 \mathrm{hrs}$ of culture (Fig. 4). After one week of culture, the longest pulse treatments killed all the protoplasts. Protoplasts electroporated for 20, 30 and $40 \mu$ s survived at 70,64 and $60 \%$, respectively, after $24 \mathrm{hrs}$ of culture. After 7 days, the highest level of survival was observed for those samples treated with the shortest electric pulses (20 $\mu$ s) (Fig. 5).

Long electric pulses decreased the number of dividing protoplasts, and a pulse longer than $40 \mu$ s totally blocked the division of electroporated protoplast-derived cells. The highest percentage (44.5\%) of protoplast division occurred in the case of $20 \mu$ s pulses. Already, a $30 \mu$ s long pulse resulted in a drastic decrease to $5.6 \%$ in cell division, which was reduced further to $2.9 \%$ with $40 \mu$ s pulses, although no significant differences were observed between 30 and $40 \mu \mathrm{s}$.

\section{Plant regeneration from electroporated protoplasts}

Among the experimental conditions for the electroporation of embryogenic cell suspension protoplasts of G. kurroo (Fig. 6A and Fig. 6B), only one combination led to callus formation and plant regeneration; namely, one single $20 \mu$ s long pulse with a field strength of $1 \mathrm{kV} / \mathrm{cm}$. It is noteworthy, that the control protoplast culture underwent numerous cell divisions and by six

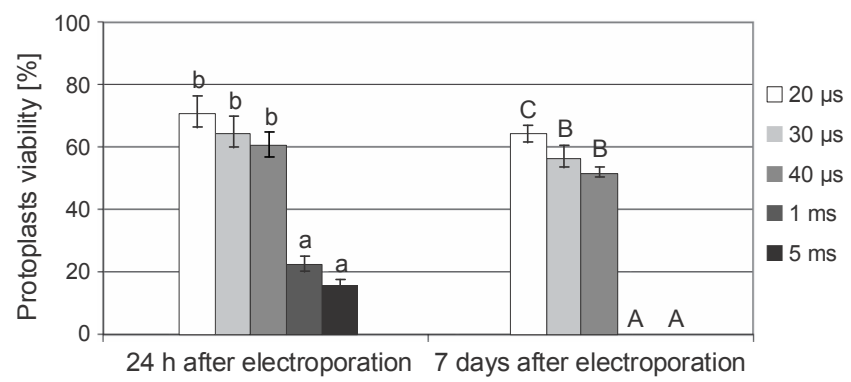

Fig. 5. The effect of the duration of electric pulse on the viability of $G$. kurroo protoplasts after application of one pulse of $1 \mathrm{kV} / \mathrm{cm}$ and incubated on ice (data marked with the same letters and size of characters are not significantly different, $p>0.05)$

weeks the beginning of small callus formation was noticed. Further, the change of culture conditions from liquid to solidified medium resulted in plant regeneration.

Electroporated protoplasts required embedding in agarose droplets supplemented with plant growth medium to start cell division. The initial division of protoplast-derived cells was observed after 5 days of culture (Fig. 6C and Fig. 6D). As expected, supplementing kanamycin to the culture medium after 7 days suppressed cell divisions of non-transformed protoplasts. A microscopic analysis confirmed the mitotic activity of transformed protoplasts which were able to reach a few cell aggregates. However, only an extremely low percentage of protoplasts in kanamycin selection conditions were able to divide and form a callus (Fig. 6E). Two months of protoplast culture in agarose droplets was sufficient for prominent callus formation (Fig. $6 \mathrm{~F}$ and Fig. 6G). Initially, the transgenic callus consisted of hydrated cells which were white or pale yellow (Fig. 6H). Only the embryogenic regions of the callus were of a deeper yellow color. On the proliferation medium, these regions underwent an intense growth and this resulted in plant regeneration of $G$. kurroo. Indirect somatic embryogenesis from the callus was the only morphogenic pathway observed in these cultures (Fig. 6I and Fig. 6J). Finally, 9 plants were regenerated and later their resistance to kanamycin was confirmed.

\section{Transgenesis confirmation assessment of gus gene expression}

No expression of gus genes on cells and calli or in collected leaf fragments was observed. In contrast to the results obtained for the transformation of cell suspensions (data not published) with $A$. tumefaciens, proto- 


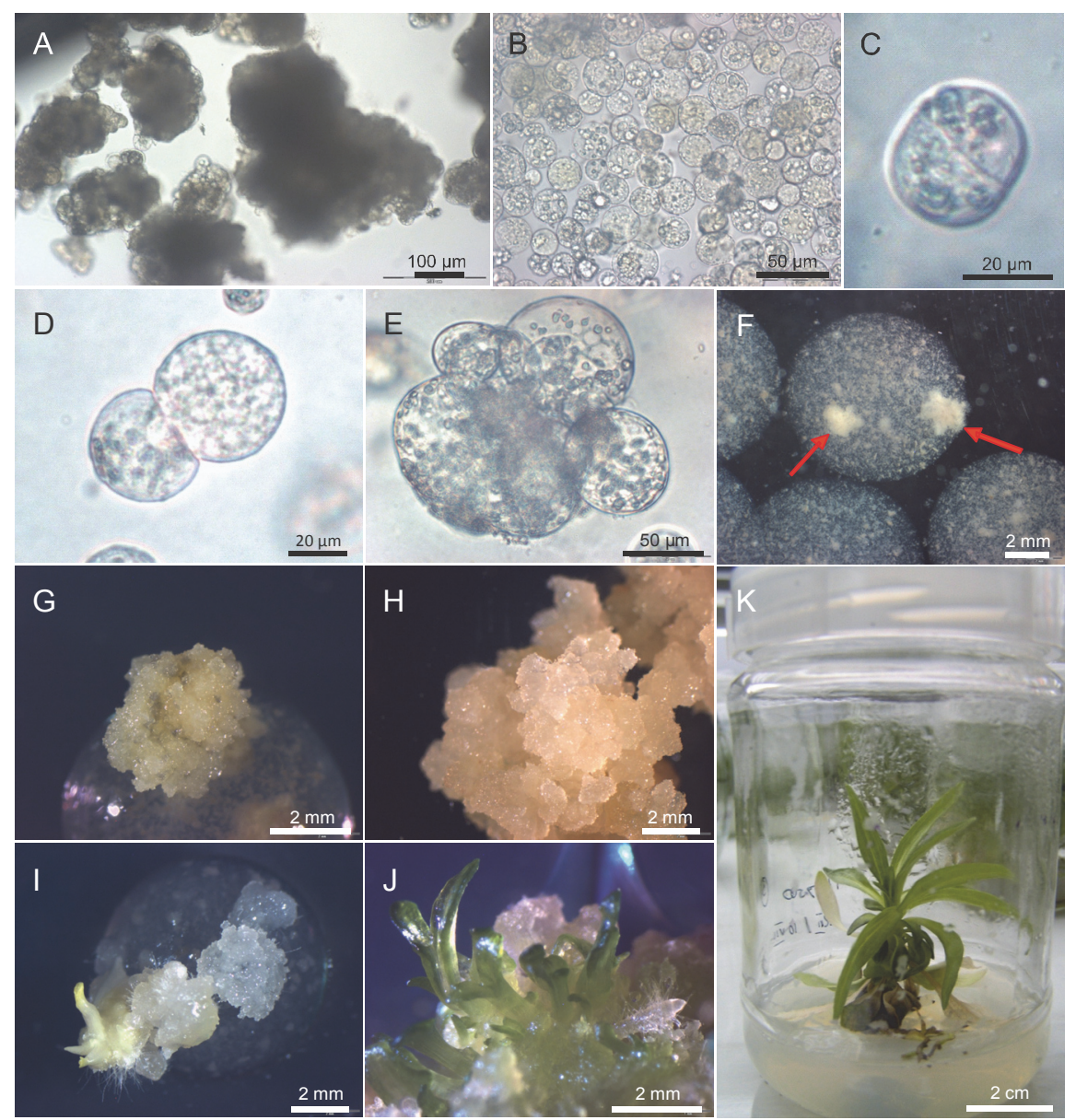

Fig. 6. G. kurroo transformant regeneration after embryogenic cell suspension protoplast electroporation: A) General view of plant cell suspension used for protoplast production, B) Freshly isolated protoplasts ready for electroporation experiments, C-D) First cell division of electroporated protoplasts after initial cell wall regeneration on $5^{\text {th }}$ day of culture, E) Few cell aggregates, F) Agarose droplet with developing mini calli, G-H) Overgrowth of transformed callus on the agar proliferation medium, I-J) Somatic embryo formation from callus derived from electroporated protoplasts, K) Transgenic plantlet of $G$. kurroo

cultured on $50 \mathrm{mg} / \mathrm{l} \mathrm{kanamycin} \mathrm{selection} \mathrm{medium.} \mathrm{All} \mathrm{cultures} \mathrm{were} \mathrm{carried} \mathrm{out} \mathrm{in} \mathrm{the} \mathrm{presence} \mathrm{of} 50 \mathrm{mg} / \mathrm{l} \mathrm{kanamycin}$

plast transformants did not show any expression of gene coding for $\beta$-glucuronidase (blue color).

\section{Discussion}

Protoplast transformation opens the possibility of obtaining genetically modified plants from single cells, thus excluding chimerism of tissue and regenerants derived from multicellular explants (Puonti-Kaerlas et al., 1992). The absence of a cell wall makes the protoplast an almost ideal explant for the exploration of electroporation (Tagu et al., 1988; Saunders et al., 1995). However, the most important prerequisite is the development of an efficient methodology of plant regeneration from protoplast cultures. In our experiments, electroporation was carried out on protoplasts derived from em- bryogenic cell suspension cultures, for which the conditions for protoplast isolation, culture and plant regeneration had previously been described (Fiuk and Rybczyński, 2007). In the discussed paper, protoplasts were placed under the extremely tough stress conditions of an electric field, various buffers and kanamycin treatment. However, this stress was partly compensated by the culture conditions. Our attempts resulted in the expression of genes of the selection agent and the establishment of a callus culture with embryogenic potential.

The chemical composition of the electroporation buffer plays an important role in protoplast survival, as does the electric field. Gupta and coworkers (1988) showed that protoplast viability of conifer plants after electroporation was reduced almost by half. In our experiments, 
buffers differed in their composition. These differences resulted in a higher survival (70.1\%) in EB1 buffer and lower (55.82\%) in EB2 buffer. High protoplast survival is related to the application of the same $\mathrm{pH}$ during protoplast isolation and electroporation. In this study, it is necessary to remember that divalent cations $\left(\mathrm{Ca}^{2+}\right.$ and $\left.\mathrm{Mg}^{2+}\right)$ play an important role in membrane stabilization, which has been discovered in protoplast fusion with both PEG and electrofusion experiments (Fromm at al., 1985; Niedz et al., 2003). Working with friable structures such as protoplasts, their plasmolemma requires some physical protection in the case of any manipulations, so incubation on ice appeared to act as the agent for biological stabilization. However, the death of the protoplast may be the result of the overheating of a sample which is located between two electrodes, and irreversible membrane damage resulting from the electric field applied. Hence, pre-cooling of the electroporation cuvette lessened the effects of such drastic protoplast treatments. It has been proved that low temperature supports the duration of the pore opening and the efficiency of transformation is higher than with an uncooled sample (Tsong and Kinosita, 1977). This research contradicted the electroporation of citrus protoplasts, where heat shock treatment at $49^{\circ} \mathrm{C}$ before an electric pulse greatly enhances transient transformation expression (Hidaka and Omura, 1993).

The only condition of electroporation with $n p t I I+$ uidA genes that permitted the development of a callus and regenerated plants in the presence of kanamycin selection medium was 1 pulse with a voltage of $1 \mathrm{kV} / \mathrm{cm}$ and a duration of $20 \mu \mathrm{s}$. Other experimental conditions studied resulted in a drastic decrease in the number of dividing protoplasts. A significant decrease in the number of the dividing protoplasts was found when the voltage was higher than $1.0 \mathrm{kV} / \mathrm{cm}$. We did not observe any significant differences between 0.75 and $1.0 \mathrm{kV} / \mathrm{cm}$. It has previously been shown that the voltage used for electroporation will change with the electroporated plant material. For Stysanthes guianensis a voltage of $0.25 \mathrm{kV} / \mathrm{cm}$ (Quecini et al., 2002) is the best, while for Citrus sinensis, Daucus carota (Bower and Birch, 1990; Niedz et al., 2003) it is $0.45 \mathrm{kV} / \mathrm{cm}, 0.5 \mathrm{kV} / \mathrm{cm}$ for Nicotiana tabacum, Glycine $\max$ (Bates, 1989; Dhir et al. 1991), and $1.0 \mathrm{kV} / \mathrm{cm}$ for Pisum sativum (Hashimoto et al., 1992). The last result was similar to our results. Most frequently, only one pulse is used; however, sometimes 6 or 10 pulses are required (Bower and Birch, 1990). The pulse duration is experimentally specified and species dependent. For protoplasts of Chinese orange a duration as long as 70$80 \mathrm{~ms}$ is the best (Niedz et al., 2003).

In our experiments, only DNA at a concentration of $50 \mu \mathrm{g} / \mathrm{ml}$ was used. A number of papers indicate $100 \mu \mathrm{g} / \mathrm{ml}$ as the most successful concentration of DNA in transient expression. The most effective transformation of Citrus protoplasts occurred in the presence of that concentration, while doubling it to $200 \mu \mathrm{g} / \mathrm{ml}$ resulted in a drastic reduction of the phenomenon (Hidaka and Omura, 1993). Not only does the concentration of the plasmid play an important role, but the form (circular or linear) of DNA should also be considered (Quecini et al., 2002). In some plants, linear DNA allowed better results to be obtained than the circular vector (Negrutiu et al., 1987; Shillito et al., 1985).

Because of the inner structure of DNA and the lack of distortions resulting from the structure of a double helix, a circular DNA is significantly less mobile in the electric field (Courey and Wang, 1983; Drew et al., 1988). The size of the linear molecule is significantly smaller because of the lack of its tertiary and quaternary structure, which helps DNA molecules to penetrate the pores of cell membranes (Tanaka, 1988).

The number of plants, only nine, derived from electroporated embryogenic protoplasts is low in comparison to the morphogenic potential of untreated protoplasts (Fiuk and Rybczyński, 2007). However, the system of selection based on kanamycin resistance seems to be very stringent and only the expression of the nptII gene ensures the survival of the protoplast and callus in the presence of $50.0 \mathrm{mg} / \mathrm{l} \mathrm{kanamycin}$. The lack of a solid cell wall at the initial stages of protoplast cultures that could act as a physical barrier, combined with a relatively early application of kanamycin, could be considered as the factors that inhibit the formation of "escapes".

The experimental system presented here is very labor-intensive and requires knowledge of protoplast culture and plant regeneration techniques. It is nevertheless worthwhile to invest in research into technology for sourcing the whole culture from a single cell.

\section{Acknowledgment}

The above studies were financially supported by Polish Government project N N302 139035. The authors would like to extend their thanks to Professor P.S. Baenziger, Ph.D. (Nebraska University, Lincoln, USA) for his critical reading of the manuscript and suggestions on English language correction. 


\section{Authors' contribution}

The authors' contributions to the research are: laboratory experiments - A. Wójcik, writing of the manuscript - J. J. Rybczyński.

\section{References}

Amita Tamar, Manhas R.H., Shrivastava R.K. (2012) Seed germination studies in Gentiana kurroo Rayle - an endangered medicinal herb. J. Med. Aromat. Plant Species 34: 168-171.

Barton C.R., Adams T.L., Zarovitz M. (1991) Stable transformation of foreign DNA into Coffea arabica plants. In: Proceedings of the $14^{\text {th }}$ International Conference on Coffee Science. July $14-19^{\text {th }}$ San Francisco, USAASIC Lausanne: 460-464.

Bates G.W. (1989) Electroporation of protoplasts. J. Tiss. Cult. Meth. 12: 121-126.

Bower R., Birch R.G. (1990) Competence for gene transfer by electroporation in a subpopulation of protoplasts from uniform carrot cell suspension cultures. Plant Cell Rep. 9: 386-389.

Courey A.J., Wang J.C. (1983) Cruciform formation in a negatively supercoiled DNA. may be kinetically forbidden under physiological conditions. Cell 33: 817-829.

Dhir S.K., Dhir S., Hepburn A., Widholm J.M. (1991) Factors affecting transient gene expression in electroporated Glycine max protoplasts. Plant Cell Rep. 10: 106-110.

Drew H.R., McCall M.J., Calladine C.R. (1988) Recent studies of DNA in the crystal. Ann. Rev. Cell. Biol. 4: 1-20.

Fernandez Da Silva R., Menendez-Yuffa A. (2003) Transient gene expression in secondarysomatic embryo from coffee tissue electroporated with gene bar and gus. Mol. Plant Pathol. 5: 527-536.

Fiuk A., Rybczynski J.J. (2007) The effect of several factors on somatic embryogenesis and plant regeneration in protoplast cultures of Gentiana kurroo (Royle). Plant Cell Tiss. Org. Cult. 91: 263-271.

Fiuk A., Rybczyński J.J. (2008) Factors influencing efficiency of somatic embryogenesis of Gentiana kurroo (Royle) cell suspension. Plant Biotech. Rep. 2: 33-39.

Freason E.M., Power J.B., Cocking E.C. (1973) The isolation, culture and regeneration of petunia leaf protoplasts. Dev. Biol. 33: 130-137.

Fromm M., Callis J., Taylor L.P., Walbot V. (1987) Electroporation of DNA and RNA into plant protoplasts. In: $M e$ thods in enzymology. Ed. Abelson J.N., Simon M.I. New York, Academic Press: 351-366.

Gupta P.K., Dandekar A.M., Durzan D.J. (1988) Somatic embryo formation and transient expression of a luciferase gene in Daglas fir and loblolly pine protoplasts. Plant Sci. 58: 85-92.

Hashimoto T., Yamada T., Tado A., Kawamata S., Tanaka Y., Sriprasertsak P.,Ichinose Y., Kato H., Izutsu S., Shiraishi T., Oku H., Ohtsuki Y. (1992) Transientexpression in electroporated pea protoplasts: Elicitor responsiveness of a phenylalanineammonia-lyase promoter. Plant Cell Rep. 11: 183-187.

Jefferson R.A., Kavanagh T.A., Bevan M.V. (1987) GUS fusions: $\beta$-glucoronidase as a sensitive and versatile gene fusion marker in higher plants. EMBO J. 6: 3901-3907.

Jomori H., Takahata Y., Kaizuma N. (1995) Plant regeneration from leave-derived calli of Gentians and their protoplast culture. Acta Horticult. 392: 81-86.

Hidaka T., Omura M. (1993) Transformation of citrus protoplasts by electroporation. J. Jap. Soc. Hort. Sci. 62: 371-376.

Kaushal S., Sidana A., Dev K. (2014) In vitro plant production through apical meristem culture of Gentiana kurroo Royle. J. Med. Plant Stud. 3: 4-9.

Latif A., Afaq S.H., Khan T.F. (2006) Antiinflammatory activity of flowertops of Gentiana kurroo Royle extract. Pharmacol. On line J. 3: 575-580.

Meng Y.-L., Gao Y.-P., Jia J.-F. (1996) Plant regeneration from protoplasts isolated from callus of Gentiana crassicaulis. Plant Cell Rep. 16: 88-91.

Murashige T., Skoog F. (1962) A revised medium for rapid growth and bioassay with tobacco tissue culture. Physiol. Plant. 15: 473-497.

Negrutiu I., Shillito R., Potrykus I., Baisini M.G., Sala F. (1987) Hybrid genes in the analysis of transformation conditions. Plant Mol. Biol. 8: 363-373.

Neumann E., Kakorin S., Tsoneva I. (1996) Calcium-mediated DNA adsorption toyeast cells and kinetics of cell transformation by electroporation. Biophys. J. 71: 868-877.

Neumann E., Schäefer-Ridder M., Wang M., Hofschneider P.H. (1982) Gene transfer into mouse lyoma cells by electroporation in high electric fields. EMBO J. 1: 841-845.

Niedz R.P., McKendree W.L., Shatters Jr. R.G. (2003) Electroporation of embryogenic protoplasts of sweet orange ( $\mathrm{C} i$ trus sinensis (L.) Osbeck) and regeneration of transformed plants. In Vitro Cell. Dev. Biol. Plant 39: 586-594.

Niedziela A., Rybczyński J.J. (2014) Primary results of 2-dimensional electrophoresis for protein studies of Gentiana kurroo Royle somatic embryos derived from long-term embryogenic cell suspensions. Acta Soc. Bot. Pol. 83: 247-250.

Ochatt S.J., Chand P.K., Rech E.L., Davey M.R., Power J.B. (1988) Electroporation-mediated improvement of plant regeneration from colt cherry (Prunus avium $\times$ pseudocerasus) protoplasts. Plant Sci. 54: 165-169.

Quecini V.M., de Oliveira C.A., Alves A.C., Vieira M.L.C. (2002) Factors influencing electroporation-mediated gene transfer to Stylosanthes guianensis (Aubl.) protoplasts. Gen. Mol. Biol. 25: 73-80.

Puonti-Kaerlas J., Ottosson A., Eriksson T. (1992) Survival and growth of peaprotoplasts after transformation by electroporation. Plant Cell Tiss. Org. Cult. 30: 141-148.

Raina R., Behera M.C., Chand R., Sharma Y. (2003) Reproductive biology of Gentiana kurroo Royle. Curr. Sci. 85: 667-670.

Raina R., Chand R., Sharma Y. (2011) Conservation strategies of some important medicinal plants. Int. J. Med. Arom. Plants 1: 342-347. 
Sambrook J., Russell D.W. (2001) Molecular Cloning: A Laboratory Manual. Vol. 1.

Shillito R.D., Saul M.W., Paszkowski J., Müller M., Potrykus I. (1985) Highefficiency direct gene transfer to plants. BioTechnology 3: 1099-1103.

Sowers A.E. (1992) Mechanisms of electroporation and electrofusion. In: Guide to electroporation and electrofusion. Ed. Chang D.C., Chassy B.M., Saunders J.A., Sowers A.E. San Diego, Academic Press: 119-138.

Tagu D., Bergounioux C., Cretin C., Perennes C., Gadal P. (1988) Direct gene transfer in Petunia hybrida electro- porated protoplasts: evidence for co-transformation with a phosphoenolpyruvate carboxylase cDNA from sorghum leaf. Protoplasma 146: 101-105

Tanaka T. (1988) Gels. Sci. Amer. 244: 124-138.

Tomiczak K., Rybczyński J. J.(2015) Autotetraploid plant regeneration by indirect somatic embryogenesis from leaf mesophyll protoplasts of diploid Gentiana decumbens L. In vitro Cell. Dev. Biol. Plant 51: 350-359.

Tsong T.Y., Kinosita K. (1977) Formation and resealing of pores of controlled sizes inhuman ery throcyte membrane. Nature 268: 438-440. 